\title{
Chapter 25 \\ Diaspora Policies, Consular Services and Social Protection for Turkish Citizens Abroad
}

\author{
Seda Aydin and Eva Østergaard-Nielsen
}

\subsection{Introduction}

This chapter aims to describe and explain the development of the main features of Turkish diaspora policies, with a particular emphasis on the area of social protection. First, it presents the general institutional framework through which Turkish authorities interact with their nationals abroad and depicts the main engagement policies outside of the area of welfare. Secondly, it illustrates the policies, programmes and services offered by the Turkish authorities to address the social protection needs of Turks abroad. The chapter focuses on five main policy areas (unemployment, guaranteed minimum resources, health care, family benefits, and pensions) and discusses the role of three main actors (consulates, diaspora institutions and home country ministries/agencies) in the creation and implementation of these policies.

Turkey's diaspora policies have gone through different stages since the start of labour migration to Europe in the early 1960s. In line with the European Union (EU) membership bid until 2007 and the Government's assertive neo-Ottomanist foreign policy that envisions the country as a global actor, Turkey has had an increasingly active diaspora engagement since early 2000s (Unver 2013; Aydin 2014; Mencutek and Baser 2018). In this period, the Turkish state has adopted a strategy of proactive institutionalisation and investment in social capital upgrading in its emigrant politics (Aksel 2014), and has implemented a number of significant measures such as granting voting rights to the citizens abroad. One main pillar of the Turkish state's approach to the nationals abroad has been to defend and protect their

\author{
S. Aydin ( $\triangle)$ \\ GBSB Global Business School, Barcelona, Spain \\ E. Østergaard-Nielsen \\ Autonomous University of Barcelona (UAB), Barcelona, Spain
}


rights before the host country authorities. The other pillar has been to consider them as political and economic contributors, courting both their political influence as 'public diplomats' and their entrepreneurial activities (Aydin 2014; Mencutek and Baser 2018). In accordance with this double approach, this chapter shows that in the area of social protection, Turkish authorities mostly assume the role of facilitating migrants' access to the welfare benefits offered in the destination countries. This is accompanied by a number of policies designed to strengthen their economic, cultural and political ties with the homeland.

In the first section of the chapter, we examine the diaspora infrastructure through which the Turkish state engages with nationals abroad. Then we present the key engagement policies illustrating the priorities and the level of engagement of Turkey with its diaspora. In the second section, we focus on welfare policies facilitating the access to social protection of Turkish nationals residing abroad.

\subsection{Diaspora Characteristics and Home Country Engagement}

\subsubsection{The Turkish Diaspora and its Relations with the Homeland}

The current composition of the Turkish emigrant population is mainly shaped by the labour migration starting in the early 1960s. Germany rapidly became the most important destination for Turkish workers, whose number increased from 7116 in 1961 to 910,500 in 1973 (Al-Shahi and Lawless 2005, p. 12). Considerable numbers of Turkish workers were also recruited in other countries such as the Netherlands, France, Austria, Belgium, as well as Switzerland, Denmark, Sweden and Norway.

Starting as a temporary labour migration, the Turkish presence in these countries quickly turned into a permanent one. Although the recruitment of Turkish workers stopped in the 1970s following the sharp economic downturn in Europe, Turkish citizens continued to migrate in other ways such as family reunification and family formation. Particularly after the 1980 coup d'état in Turkey, and later due to the Kurdish conflict in Southeast Turkey, a political diaspora was added to the labour diaspora, which was followed by irregular migration in the 2000s (Sirkeci et al. 2012). Today, the highest numbers of Turkish citizens reside in Germany $(3,081,113)$, France $(649,482)$, the Netherlands (396,555), Austria $(279,390)$ and Belgium $(269,861) .{ }^{1}$ These countries are followed by the United States of America (USA230,377) which mainly hosts professionals, students and clandestine migrants providing unskilled or semi-skilled labour (Akcapar 2009).

In the early years of labour migration to Europe, the overall strategy of the Turkish state was to facilitate remittance flows and assist the return of migrants. As

\footnotetext{
${ }^{1}$ Calisma ve Sosyal Guvenlik Bakanligi (Ministry of Labour and Social Security) (2018). https:// www.csgb.gov.tr/. Accessed 20 February 2018.
} 
it became clear in the early 1970s that Turkish migrants were settling permanently in Europe, Turkish authorities mainly leaned towards new measures against cultural assimilation, as well as policies that would encourage return such as a return program in collaboration with United Nations Development Programme. A key development in this era was the engagement of the Presidency of Religious Affairs with Turks abroad, sending imams to Europe from 1971 (Aksel 2014, p. 202).

The 1980s witnessed a further involvement of the Turkish state in emigrant policies, due to the political emigration of opposition groups in the aftermath of the 1980 coup d'etat, and the emerging threats to the overall wellbeing of Turkish citizens abroad due to rising xenophobia and strict migration policies of the receiving countries (Østergaard-Nielsen 2003; Kadirbeyoglu 2007; Mügge 2012; Aksel 2014). In this context, the Turkish state mainly aimed at controlling and improving the conditions of the Turkish population in Europe. Among the most significant policy steps in this decade were the implementation of the dual citizenship law for the first time in 1981, sending Turkish teachers and imams to destination countries, the establishment of the Higher Coordination Council for Workers, and legislations on voting at customs in 1986 (Aksel 2014, p. 204).

In the 1990s, a new set of policies was introduced, encouraging the political and social participation of Turks abroad, such as the Pink Card which granted a number of rights to emigrants who gave up Turkish citizenship (Kadirbeyoglu 2010; Aksel 2014). According to Aydin (2014, p. 9), "two aims or intentions lay at the heart of Turkish diaspora policy in this decade: the successful integration of all people from Turkey in the countries that received them, and support of migrants in their demands for cultural rights." Yet, Mencutek and Baser (2018) note that, due to the problematic security and economic conditions within Turkey, the Turkish state did not have the capacity to adequately address the needs of the Turks abroad. Rather, "homeland security had become dominant in the state's approach to its interactions with migrants abroad" in this era (2018, p. 8).

The 2000s marked the beginning of a transformation process in Turkey's domestic and foreign politics, which has had significant effects on its diaspora engagement strategies. Under the rule of the Party for Justice and Development (Adalet ve Kalkınma Partisi, AKP), Turkish foreign policy adopted neo-Ottoman tones symbolizing new geopolitical ambitions. The Turkish state defined new aims such as foreign policy activism and playing the role of a bridge and model country. Also, an emphasis on multiple geographical, historical and religious identities went hand in hand with the generation of a Muslim nationalism on the basis of a historic Turkish and Ottoman identity (Aydin 2014, p. 11). In this changing foreign policy context, new dimensions were introduced to Turkish diaspora policies. Aydin (2014, p. 13) underlines that the three main features that characterised this period are the explicit definition of Turks abroad as a "diaspora", ${ }^{2}$ the Turkish state's engagement with this

\footnotetext{
${ }^{2}$ In the legislative language, Turks abroad are generally referred to as "Turkish citizens" (e.g. the Law on the Establishment and Duties of the MFA No: 6004). More recently, a key institution in Turkish diaspora politics, the Presidency for Turks Abroad and Related Communities (YTB), has adopted the term "Turkish diaspora" in addition to "Turkish citizens", to describe the Turkish
} 
diaspora as a part of public diplomacy, and connecting this policy with a new view of the nation compatible with multiple Muslim identities. Mencutek and Baser $(2018$, p. 8$)$ argue that in this period, "Turkey moved from being a managed labour state to a global-nation state that adopts many diaspora policies and provides emigrant populations with a greater number of rights."

This period follows the state's shifting perceptions of the Turks abroad from remittance machines to Euro-Turks which are unlikely to return, but maintain transnational ties to their homeland (Østergaard-Nielsen 2003; Aksel 2014, p. 204). According to Mencutek and Baser (2018), in the area of culture, the main concern of the Turkish state is to establish strong relations with second and third generation emigrants abroad. As regards the economic policies, they write: "Turkey is interested in the entrepreneurial activities of Turks abroad, their contribution to building trade relations, furthering economic growth, and strengthening bilateral relations/ export ties." (2018, p. 9) In the area of citizenship, more rights have been conceded to Turks abroad (such as the external voting rights), and the scope of rights for former citizens has been extended. Overall, in this period, the Turkish state considers the Turkish diaspora both as a resource to tap into in the context of transnational policy-making and lobbying procedures and as an important element of its imagined political community, which it must protect as an ambitious actor in the international arena (Mencutek and Baser 2018).

\subsubsection{Diaspora Infrastructure}

\subsubsection{The Consular Network}

Turkey's consulates and honorary consulates are supervised by the General Directorate for Consular Services of the Ministry of Foreign Affairs (MFA ${ }^{3}$ ). Based on the Law on the Establishment and Duties of the MFA No 6004, ${ }^{4}$ the duties of the consulates include providing consular services and protection to Turkish citizens and legal entities with Turkish nationality, providing visa services for foreign nationals, performing the tasks listed in the Vienna Convention on Consular Relations of 1963 and fulfilling duties given by Turkish embassies. According to the same law, honorary consulates are also responsible for protecting and developing the interests of Turkey, ensuring consular protection for Turkish citizens and legal entities with Turkish nationality, conducting consular procedures if specifically authorized, and fulfilling other duties assigned by the embassy.

emigrants abroad. The policies of the YTB also addresses "the diasporas of related communities", with which Turkey has "shared historical and cultural ties."

${ }^{3}$ Disisleri Bakanligi (Ministry of Foreign Affairs) (2018). http://www.mfa.gov.tr/. Accessed 20 February 2018.

${ }^{4}$ http://www.mfa.gov.tr/data/BAKANLIK/mevzuat-2013.pdf. Accessed 20 February 2018. 
In addition to the traditional consular services, other services are offered by the attachés and advisors who are appointed by the Turkish ministries to work in consulates or embassies. The attachés and advisors are mainly in charge of diplomatic tasks, while also providing information and other services to the nationals abroad on the host and home country services and policies. Their general duties are defined by their own ministries, while their specific tasks are determined based on the needs of the diaspora.

Attachés and advisors are appointed according to the needs of the emigrants, so they are not in service in every host country. The attachés/advisors of the Ministry of Labour, Social Services and Family are the most relevant ones in the context of this chapter. This Ministry was established by the first Government after the implementation of the presidential system in June 2018 and is the unification of the Ministry of Labour and Social Security and the Ministry of Family and Social Policies. While the services of the former Ministry of Labour and Social Security are more widespread and established in 23 countries, the first attaché of the former Ministry of Family and Social Policies was appointed in 2015 to Dusseldorf. In 2017, plans were announced to appoint further seven advisors (in Berlin, Paris, Brussels, Stockholm, London, Oslo, The Hague) and 13 attachés (in Cologne, Munich, Hamburg, Stuttgart, Dusseldorf). As of March 2020, the Ministry of Labour, Social Services and Family has 30 advisors and 27 attachés in 29 countries. $^{5}$

Turkey also offers mobile consular services. These services are not defined in the law and their scope depends on the consulate, although not all consulates offer them. An online search suggests that consulates in large countries such as Canada, the USA, Australia, and China tend to offer these services more often. This include assistance with military enlistment, citizenship application, civil registry (marriage, birth, ID card, etc.), address declaration, and criminal record declaration. The upcoming mobile service days are generally announced on the webpages of the consulates.

\subsubsection{Institutions at the Sub-ministry Level}

One of the main institutions at the sub-ministry level is the General Directorate for Consular Services of the Ministry of Foreign Affairs, whose duties are defined by the Law on the Establishment and Duties of the MFA No 6004. The General Directorate is responsible for the consular relations, as well as the coordination and execution of the related meetings and negotiations. Consular services and issues regarding Turkish nationals abroad are under the responsibility of this Directorate.

The General Directorate of Foreign Affairs and Services for Workers Abroad, supervised by the recently established Ministry of Labour, Social Services and Family, is another diaspora engagement institution. Founded in 1967, it is

\footnotetext{
${ }^{5} \mathrm{https} / / / \mathrm{www}$. ailevecalisma.gov.tr/digm/contents/dis-temsilciliklerimiz/genel-bilgiler/. Accessed 20 February 2018.
} 
responsible for protecting and improving the rights and interests of Turkish workers abroad, by offering help regarding their problems abroad or after return. It also aims at monitoring employment types and rates of the Turkish labour force abroad, developing related policies, coordinating social security agreements with other countries, and keeping contact with international institutions of labour and social security. ${ }^{6}$

One of the most significant institutional changes at the sub-ministry level was the introduction of the Presidency for Turks Abroad and Related Communities (YTB, Yurtdlşı Türkler ve Akraba Topluluklar Başkanlığl) in 2010. ${ }^{7}$ The YTB worked under the supervision of the prime ministry until Turkey's transition to the presidential system in June 2018. Since then, it works under the authority of the Ministry of Culture and Tourism. The YTB constitutes the main institutional basis for the state's relations with Turkish citizens, (former) nationals and kin and co-ethnic communities abroad, as well as international students of Turkish and Muslim origin in Turkey. Its main aim is to strengthen and maintain social, cultural and economic relations with Turkish citizens and other Turkish origin communities abroad. Also, it considers the international students who are YTB scholarship-holders all over the world as volunteer ambassadors of Turkey. The YTB fosters relations with Turks abroad mainly through meetings with the Turkish migrant associations and an advisory committee of selected migrants called the Consultative Board of Turkish Citizens Abroad (Yurtdışı Türkler Danışma Kurulu).

In 2018, the YTB for the first time directly addressed the issues of family and social services for the Turks abroad with the Family and Social Services Experts Training and Consultation Program and scholarships for expert training. Also in 2018, the YTB started a scholarship program for expert training of lawyers who received their high school education and law degrees abroad and who are affiliated to the bars of the host countries. According to its website, the aim of the program is to train legal experts to fight Islamophobia, discrimination, and violation of rights against Turks abroad. Scholarship holders are expected to work with an NGO determined by the YTB to offer consultancy services to the Turks abroad, as well as do research and prepare reports on related topics.

The YTB also places a special emphasis on the issue of education and cultural mobility of Turks abroad, supporting the children and the youth through weekend schools, scholarships and internships for nationals and Blue Card holders who live abroad. For instance, the 'Young Leaders Program' (called the Diaspora Youth Academy in 2018) was designed to help create role model individuals for the Turkish diaspora since 2013. Moreover, the first Human Rights Education Program was held during the summer of 2017 with the aim of training undergraduate students on issues such as human rights protection, public advocacy, and the function of Turkey's administrative system and public institutions.

\footnotetext{
${ }^{6} \mathrm{https}: / /$ www.csgb.gov.tr/diyih/contents/genelmudurluk/gorevlerimiz/. Accessed February 2018.

${ }^{7}$ For further details regarding YTB's activities and aims, see: https://www.ytb.gov.tr/en/corporate/ institution. Accessed 20 February 2018.
} 


\subsubsection{National-Level Public Institutions}

One of the earliest national-level public institutions of the diaspora infrastructure is the Islamic Union of the State Office of Religious Affairs (DITIB, Diyanet Issleri Türk İslam Birlığl) established in 1984 in Germany to coordinate the religious associations and maintain links with emigrants (Østergaard-Nielsen 2003; Aksel 2014; Mencutek and Baser 2018). Originally founded as a religious association, DITIB gradually became the umbrella organisation of the mosque associations in Germany. Among the main aims cited on its webpage are undertaking religious activities, establishing interreligious dialogue with other groups, encouraging Turks to embrace the Turkish culture and organizing cultural and social activities. According to Aydin (2014, p. 17), "DITIB is subject to the management and control of the Turkish state Presidium for Religious Affairs (DIBB) and thus represents a view of Islam that is compatible with the official state policies.” The primary focus of DITIB is to provide religious services such as hajj and umrah Islamic pilgrimage trips to Mecca, and funeral funds for the repatriation of the deceased to Turkey. ${ }^{8}$ It also has departments dedicated to the youth, women, consulting on social and family affairs, intercultural and interreligious dialogue, and educational and cultural topics.

In other host countries, similar institutions, usually known as Diyanet, were established in the form of foundations, such as the Turkish Islamic Foundation of Belgium (Belcika Diyanet Vakfi), the Turkish Islamic Foundation of the Netherlands (Hollanda Diyanet Vakfi) and DITIB France. Imams working with these foundations are civil servants whose salaries are paid by the Turkish Government, which creates an organic link between these foundations and the Presidium for Religious Affairs (DIB, Diyanet İşleri Başkanlı̆̆ ) (Yanasmayan 2010, p. 146). Underlining the influence of the DIB over these foundations, Doomernik (1995, p. 51) notes "since mosque organizations usually have tight budgets and employees are very expensive, it immediately becomes clear how powerful this Diyanet [DIB] trump card is." The scope of the services provided by these foundations varies from one country to another, as there is no unified program.

The World Turkish Business Council (DTIK, Dünya Türk İs Konseyi), founded under the semi-autonomous Foreign Economic Relations Board (DEIK, Dış Ekonomik Ilisskiler Kurulu) in 2007, represents the main institution through which Turkey maintains ties with the "Turkish business community" abroad (also see Mencutek and Baser 2018). ${ }^{9}$ According to its website, DTIK aims "to boost the commercial and economic relations among the Turkish business community settled outside Turkey, to strengthen and disseminate the Turkish diaspora further, to create

\footnotetext{
${ }^{8}$ Being buried in the home country is an important issue for most Turks. According to der Spiegel, "Islamic undertakers estimate that 70-80\% of Muslim immigrants in Germany arrange to have their bodies sent home mainly to Turkey." Along with religious reasons, this tendency also has financial and legal reasons. For example, Muslims prefer to be buried in shrouds, but laws in most German states require a coffin for a burial. (http://www.spiegel.de/international/homeward-boundmuslims-in-germany-choose-to-be-buried-abroad-a-462035.html. Accessed 20 February 2018.) ${ }^{9}$ http://www.dtik.org.tr/Konsey YapilanmasiTanitim.html. Accessed 20 February 2018.
} 
one main centre for all kinds of problems that the Turkish entrepreneurs face abroad, and to lead the efforts to establish a stronger image for Turkey in the world."

The Yunus Emre Foundation (YEV, Yunus Emre Vakfi) and the Yunus Emre Cultural Centres (YEKMs, Yunus Emre Kültür Merkezi), founded in 2007, have been the central institutions for the promotion of Turkish culture. Their responsibilities are stated as "presenting Turkish cultural heritage, promoting cultural exchange, making information about Turkey available and providing educational services on Turkish language and culture and on the country's arts" (Aydin 2014). Although they are not specifically designed to meet the needs of the Turks abroad, the services they offer, such as Turkish language and culture courses, are arguably addressed to them as well.

\subsubsection{Consultative Bodies}

The Consultative Board of Turkish Citizens Abroad (Yurtdışı Türkler Danışma Kurulu) was the main consultative body through which the Turkish nationals abroad can express opinions about specific areas of interest. It was founded in 2010 by the same law that regulates the YTB and was active until the end of $2016 .{ }^{10}$ It consisted of maximum 70 members living in countries which host the largest number of Turkish citizens. Its members, with or without Turkish citizenship, were nominated by the presidency of the YTB and appointed by the president of the Board itself. Their duties include advising on problems of Turks abroad; advising on the equal participation of the Turks abroad to the economic and social life in their countries of residence; advising on the detection of the needs of the Turks abroad that should be met by the Turkish Republic; advising on activities to raise international consciousness on xenophobia, racism and discrimination; organizing workshops, meetings, conferences about the issues under its responsibility; participating to similar events organised by other institutions. The Board met at least once a year. It took decisions by majority vote, but the opinions of the MFA were given priority in the decisionmaking process. It was not obligatory for the Turkish authorities to consult this Board.

\subsubsection{Diaspora Infrastructure of the Turkish Political Parties}

With the new legislation that gives extraterritorial voting rights to the Turkish nationals abroad since 2012, the Turkish political parties have increased their organisational capacities abroad. To deal with the concerns of the nationals abroad, mainstream parties have created bodies such as the Foreign Affairs Office (AKP) and the Coordination Office for Organisation Abroad (CHP, Cumhuriyet Halk Partisi, Republican People's Party). These parties have also opened representative units in the host countries.

\footnotetext{
${ }^{10}$ The Consultative Board is at the phase of organisational restructuring at the moment of writing of this chapter. https://www.ytb.gov.tr/kurumsal/yurtdisi-vatandaslar-danisma-kurulu-yvdk. Accessed 20 February 2018.
} 


\subsubsection{Key Engagement Policies}

While diaspora policies remained relatively inefficient until the 1980s, Article 62 of the 1982 Constitution prepared the legal framework for the emigrant affairs for the first time, decreeing that the state should "take all necessary measures to ensure family unity, the education of children, and the social security of Turkish citizens working abroad, to secure their ties to their homeland and to help them to return." Through the 1990s, Turkey's interest in diaspora engagement increased, but remained limited to advisory boards and parliamentary commissions. An intensive period of engagement and institutionalisation started in 2003 by a parliamentary investigation commission attending to the problems of the Turkish nationals abroad and calling for a separate directorate for emigrant affairs (Mencutek and Baser 2018).

Scholars explain the major changes in diaspora engagement policies since the early 2000s by the EU accession trajectory (which is now abandoned), and the transition to an active foreign policy with neo-Ottoman connotations, which puts emphasis on public diplomacy (Unver 2013; Aydin 2014; Mencutek and Baser 2018). Following Erdogan et al. (2013), Mencutek and Baser (2018) write that the Turkish state has created a unified set of diaspora policies with the following objectives: to defend emigrants' rights, especially regarding the prevention of discrimination, racism and Islamophobia; to improve the competence and qualifications of emigrants; to foster emigrants' relations with the homeland, and their role in Turkish politics, foreign policy and the economy; and to reflect the broadening of Turkey's conceptions of citizenship, belonging and identity.

In this regard, the granting of the external voting rights in 2012, and the foundation of institutions such as the YTB, the DTIK and the YEKMs, are considered among the main policy steps in diaspora engagement. Mencutek and Baser (2018) also underline the increasing quality of the consular services in the last decade, following the orders of the Ministry of Foreign Affairs to develop closer relations with the Turks abroad (Mencutek and Baser 2018). To this, one can also add the abovementioned expansion of the services of the attachés and advisors working within the body of the consulates and embassies.

Several changes were also made regarding citizenship policies. First, in 2004, the 'pink card', which was issued to the Turks abroad who gave up Turkish citizenship, was substituted by a 'blue card'. In 2009, with the Turkish Citizenship Law No 5901 , the scope of the rights guaranteed by the blue card was extended. ${ }^{11}$ Accordingly, blue card holders can enjoy all the rights granted to Turkish citizens, except the right to vote, the right to work as a state officer, the right to import vehicles and household goods without taxation, as well as the military service obligations (Mencutek and Baser 2018).

In the economic realm, several policies have been implemented to encourage investment and economic engagement of the Turks abroad. With a change in the

\footnotetext{
${ }^{11}$ http://www.resmigazete.gov.tr/eskiler/2009/06/20090612-1.htm. Accessed 20 February 2018.
} 
Law on Value Added Tax No 6824 in $2017,{ }^{12}$ Turkish nationals who live abroad for more than 6 months with work and/or residence permits and foreign non-profit organisations in Turkey enjoy the same rights as foreign investors residing abroad to buy real estate without VAT payment, as long as the payment is made to real or legal persons in Turkey. Moreover, until 2017, Turks abroad could benefit from cash repatriation (varlık barlşı) based on Law No 6736, which annulled monitoring, taxing and charging fees in the transfer of money and other assets from abroad. This regulation was repealed in June 2017 due to the Tax Information Exchange Agreement among the countries of the Organisation for Economic Cooperation and Development (OECD). With a new regulation introduced by Law No 7143, a new cash repatriation policy has been implemented since July $2018 .{ }^{13}$ This law guarantees exemption from fees and taxation for individuals who transfer their assets such as money, gold, securities and other capital market instruments to Turkey and declare them to Turkish banks.

\subsection{Diaspora Policies and Social Protection in Turkey}

In a context of intensified diaspora engagement policies, which mainly aim at defending the rights of the emigrants in the host countries and promoting their economic and political contributions to Turkey, social protection policies offered by the Turkish state to its nationals abroad remain limited. Consulates and attachés mainly play a role in the dissemination of information regarding the social protection regulations of Turkey and the host countries and provide assistance in related paperwork. Until 2018, the main social services offered by the Turkish state or its diaspora institutions to nationals abroad were repatriation services for the deceased, health aid for those who benefit from health coverage in a number host countries, right to retirement from abroad, and child support. In 2018, the role of the YTB, which is the main diaspora institution, has been increased with the aforementioned programs and scholarships on family, social services and legal affairs. The YTB mainly aims at defending and protecting the Turks abroad in relation to host country authorities in these matters. Yet, counselling and therapy services through NGOs constitutes a new example of the institution's involvement in the direct provision of social services.

Regarding the most relevant social protection services, such as the in-cash and in-kind aids by the consulates or other diaspora institutions, Turkey does not have any publicly announced policies. Indeed, the Consular Guide for Travellers Abroad prepared by the MFA clearly states that consulates and embassies do not have public

\footnotetext{
${ }^{12}$ https://www.verginet.net/Dokumanlar/2017/6824-Sayili-Kanun-Vergi-Indirimi.pdf. Accessed 20 February 2018.

${ }^{13}$ https://www.gib.gov.tr/7143-sayili-kanunun-tebligleri. Accessed 20 February 2018.
} 
funds for in-cash aids. ${ }^{14}$ Exceptional examples are the social aid programs organized by the Diyanet foundations in the host countries. For example, the Turkish Islamic Foundation in the Netherlands (Hollanda Diyanet Vakfi) collaborates with Dutch NGOs such as the food banks to help the poor regardless of their religious and ethnic background.

Repatriation aid in case of emergencies such as wars or natural disasters is listed as the responsibility of the consulates in the Consular Guide for Travellers Abroad. However, there is no detailed description of this policy, which is likely to be discretionary. Repatriation of deceased bodies has been addressed by the Funeral Funds of DITIB in Germany and the corresponding foundations in other countries, which work like a solidarity fund with monthly membership fees. Overall, informing, assisting and defending the Turkish nationals with respect to social protection procedures of host countries is the main priority of the Turkish diaspora policies in this dimension.

As for the policy of information dissemination, similar to the attachés/advisors taking charge of dissemination of information in the host countries, the YTB offers an online guide called "Guide for Citizens Abroad" ${ }^{15}$ This guide presents information about the services of the Turkish state on a series of citizenship affairs, including the procedures for obtaining a passport abroad, customs regulations, Blue Card regulations, as well as health, social security and social services policies. As its name suggests, the above-mentioned Consular Guide for Travellers Abroad by the MFA is designed for the Turkish citizens travelling to other countries, rather than the emigrants living abroad. Notwithstanding, it may be helpful for emigrants, as well, as it gives advice and describes the responsibilities of the consulates in a number of cases such as hospitalization, detention, and emergency situations.

\subsubsection{Unemployment}

Social protection services for the Turkish nationals abroad in the area of unemployment are limited. A general policy of consulate services such as training, cash or in-kind benefits or repatriation assistance for the unemployed emigrants does not exist. Although there are no specific descriptions or unified regulations, some consulates circulate job offers and organize activities where employers can meet Turkish nationals. Consulates announce such opportunities in their websites and by mailing lists. As there is no specific registry or description of these services, the only way to identify them is to look through the announcement pages of each consulate. For example, in May 2016, Berlin consulate hosted the second German-Turkish Professional Training Fair, where Turkish nationals had the chance to meet German

\footnotetext{
${ }^{14}$ http://www.mfa.gov.tr/yurt-disina-seyahat-edeceklere-konsolosluk-rehberi.tr.mfa. Accessed 20 February 2018.

${ }^{15}$ https://www.ytb.gov.tr/yurtdisi-vatandas-rehberi. Accessed 20 February 2018.
} 
companies, German Pension Insurance Institute, Chamber of Craft and Related Trade Workers of Germany, and the Turkish-German Chamber of Industry and Trade.

Protecting and improving the rights and interests of Turkish workers abroad and helping with their problems abroad are stated among the responsibilities of the Directorate of Foreign Affairs and Services for Workers Abroad of the Ministry of Labour, Social Services and Family. The attachés/advisors of this Ministry assist nationals abroad in dealing with local regulations on unemployment, including getting access to unemployment benefits in the host country. Assistance includes providing information and advocacy before the local authorities, as well as helping with the paperwork and applications to the local authorities, collaborating with the latter in professional training programs, etc. There are advisors/attachés in 23 countries. In Germany, their services are a bit more extended due to the large Turkish population. For example, the office of the attaché in Germany has a detailed website where one can find Turkish translations of German laws and regulations on many topics including unemployment benefits.

\subsubsection{Health Care}

In the area of health care and invalidity, consular services, such as training to prevent health risks abroad, cash or in-kind benefits or repatriation assistance in case of illness, do not exist. In a number of countries, consulates and attachés offer assistance in the preparation and submission of administrative documents for the health aid program for Turkish nationals who have health coverage abroad.

One of the most relevant policies in the area of health care is the above-mentioned health aid program for individuals (both Turkish nationals and non-nationals) who have health coverage in countries which have signed bilateral social security agreements with Turkey. ${ }^{16}$ Accordingly, individuals paying social security contributions in Germany, the Netherlands, Belgium, Austria, France, Northern Cyprus Turkish Republic, Macedonia, Romania, Bosnia and Herzegovina, the Czech Republic, Luxemburg, Croatia, Serbia and Montenegro are entitled to free health care during their stay in Turkey, upon paying a contribution fee. ${ }^{17}$ To receive this service, they need to submit the necessary documents obtained from the social security institute in the host country to the social security institute in Turkey. The service includes coverage of medical visits, treatments, medicine, and hospitalisation by the Social Security Institute of Turkey. Among these countries, individuals who have health coverage in Austria, Belgium, France, the Netherlands, and Germany receive a permanent YUPASS number for the health services indicated above, while the others are provided a "Health Aid Document", the duration of which is ascertained by the

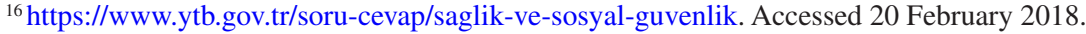

${ }^{17} \mathrm{Fees}$ for outpatients depend on the institution. For medical coverage, working individuals pay $20 \%$, whereas the retired pay $10 \%$.
} 
social security institute of the country of residence. YUPASS originally started as a part of the social security agreement between Germany and Turkey. Austria, Belgium, France, and the Netherlands were included in the YUPASS system in 2017.

In the case of Germany, services of the attachés/advisors of the Ministry of Labour, Social Services and Family are relatively extensive. The attaché office of the former Ministry of Labour and Social Security offers an elaborated webpage to assist nationals abroad in dealing with health regulations in host and home countries, by mainly providing Turkish translations of German laws. The attaché office of the Ministry of Family and Social Policies provides consultancy services on invalidity benefits given by German institutions. Services include providing information, helping with filing applications, advocacy before German institutions, and referring the applicants to relevant NGOs or other institutions.

\subsubsection{Pensions}

Starting in the 1960s, Turkey has signed bilateral social security agreements that facilitate the portability of pensions with 28 countries, including Austria, Belgium, Canada, Denmark, France, Germany Luxemburg, Norway, the Netherlands, Sweden, and Switzerland. ${ }^{18}$ As of January 2015, the scope of the agreement with Germany includes old-age pensions, survivor's pensions, invalidity benefits, health insurance benefits, occupational diseases, work injuries, and family allowances that are unilaterally covered by Germany (Holzmann 2016, p. 16). According to Holzman (2016, p. 15), despite significant changes in the characteristics of migration and the situation of the labour market, the scope of these agreements tend to "reflect the migration situation of decades ago and the labor market goals of the 1950s and 1960s."

Based on the Turkish Law on Retirement from abroad No 3201, ${ }^{19}$ the attachés of the Ministry of Labour, Social Services and Family are responsible for providing assistance and information to Turkish nationals regarding access to home country pensions. According to this law, which dates back to 1985, nationals working abroad can pay SSI premiums to Turkey for the time they work abroad. Although returning to Turkey is stated as a condition for receiving pensions, the website of the YTB mentions that the condition of return can also be interpreted as "no longer working abroad and not receiving any host country pensions or aids." ${ }^{20}$ The requirements are to be a Turkish citizen, to file a written application and to document the time spent abroad. As a proof of return, the applicants need to present the entry stamps on their passports. The attachés receive the applications and if the evaluation is favourable, they issue the "Service Abroad Document" (Yurtdlşı Hizmet Belgesi) to the

\footnotetext{
${ }^{18} \mathrm{http}: / /$ www.sgk.gov.tr/wps/portal/sgk/en/detail/social_sec_agree. Accessed 20 February 2018.

${ }^{19} \mathrm{http}: / /$ www.mevzuat.gov.tr/MevzuatMetin/1.5.3201.pdf. Accessed 20 February 2018.

${ }^{20} \mathrm{https} / / /$ www.ytb.gov.tr/soru-cevap/saglik-ve-sosyal-guvenlik. Accessed 20 February 2018.
} 
applicants. Subsequently, this document should be submitted to the SSI in Turkey by the applicants themselves. Moreover, the SSI in Turkey offers consultancy by phone for inquiries regarding retirement from abroad on issues such as how to file an application, and how to receive pensions.

\subsubsection{Family-Related Benefits}

In the area of family-related diaspora policies, the consulates and the attachés of the Ministry of Labour, Social Services and Family help Turkish nationals obtain birth certificates for children born abroad and help prepare their paperwork for child support. Based on the Population Services Law No $5490^{21}$ and the Civil Law No 4721, ${ }^{22}$ all Turkish citizens have to declare the birth of their children to the Turkish consulate within 60 days. Documents issued by foreign authorities need to be sent by mail or handed in personally to the consulate by either of the parents. In principle, declarations are made to the mission that corresponds to the place of birth of the child. If the parents choose to declare it in another country, which has not signed the International Commission on Civil Status contract on the issuing of multilingual birth certificates, the application is double-checked by the consulate that is responsible for the place of birth of the child.

Based on Decree No $633^{23}$ dating back to 2015, the Ministry of Family and Social Policies ${ }^{24}$ pays a one off child benefit per child born to nationals abroad or in Turkey, as well as to the former Turkish citizens who are Blue Card holders. The amount is $300 \mathrm{TL}$ (around 50 Euros) for the first child, $400 \mathrm{TL}$ (around 65 Euros) for the second child, and 600 TL (around 100 Euros) for each of the following children. Applications by nationals abroad are made to the consulates and embassies with the birth certificate of the child and a petition.

One of the most significant institutional developments in the area of family is the appointment of the Dusseldorf attaché of the Ministry of Family and Social Policies for the first time in 2015. With this step, the Ministry aims to work on detecting and solving the problems faced by nationals abroad, come up with suggestions on how citizens abroad can benefit more effectively from the host country social services, defend the rights of nationals abroad, follow social security regulations in host countries and collaborate with host country authorities. ${ }^{25}$ The Dusseldorf attaché addresses the problems of Turks in all parts of Germany until the opening of new

\footnotetext{
${ }^{21}$ http://www.mevzuat.gov.tr/MevzuatMetin/1.5.5490.pdf. Accessed 20 February 2018.

${ }^{22} \mathrm{https} / / /$ www.mevzuat.gov.tr/MevzuatMetin/1.5.4721.pdf. Accessed 20 February 2018.

${ }^{23} \mathrm{http}: / /$ www.resmigazete.gov.tr/eskiler/2011/06/20110608m1-1.pdf. Accessed 20 February 2018.

${ }^{24}$ From June 2018 on, the new Ministry of Labour, Social Services and Family

${ }^{25}$ Aile ve Sosyal Politikalar Bakanligi Dusseldorf Ateseligi (Dusseldorf attaché of the Ministry of Family and Social Policies) (2018). https://dusseldorf.aile.gov.tr/. Accessed 20 February 2018.
} 
similar offices in Hamburg, Stuttgart, Cologne and Munich, which was declared by the Ministry in 2017. ${ }^{26}$

In 2018, the YTB has for the first time directly addressed the issues of family and social services for the Turks abroad. Together with the Family and Social Services Experts Training and Consultation Program, it organised a meeting of experts on the cultural, social, legal and demographic dimensions of the family structure of Turks abroad in September 2018. ${ }^{27}$ Only Turkish nationals, or Blue Card holders who received their graduate and/or post-graduate degrees in a number of host countries, are eligible for this program. Moreover, the YTB offers scholarships for expert training for the Turkish nationals and Blue Card holders who receive graduate and post-graduate degrees in the host country institutions in fields related to family issues and social services. ${ }^{28}$ The goal of these scholarships is to increase the variety of family-related support, therapy, consultancy and social services for Turks abroad and to contribute to the formation of human resources in this field. In return, scholarship holders are expected to volunteer in NGOs determined by the YTB which address the needs of Turkish citizens.

As mentioned earlier, the YTB also plays a role in family services as they offer courses and scholarships to children abroad. The YTB funds the Weekend Schools Program, which is organised by NGOs and other educational institutions and aims to provide Turkish, history, religion, culture and arts classes to Turkish children abroad with a duration of 32 to 40 weeks. It also supports NGOs abroad, which work in the promotion of bi-lingual preschool education. Another institution involved in the education of children is the Directorate of the Religious Affairs, whose advisors (mostly imams) offer religion classes.

\subsubsection{Economic Hardship}

The only service that the Turkish state offers to nationals abroad in the realm of social assistance is the help provided by the attachés of the former Ministry of Labour and Social Security. This assistance consists of providing information and advocacy regarding the procedures and regulations in the host country. As mentioned earlier, the attaché office in Germany offers a detailed website where one can find Turkish translations of German laws and regulations on many topics that also cover the German scheme of guaranteed minimum resources.

\footnotetext{
${ }^{26} \mathrm{http} / / / \mathrm{www}$.hurriyet.com.tr/dunya/almanyanin-4-kentinde-aile-ataseligi-aciliyor-40392454. Accessed 20 February 2018.

${ }^{27}$ https://www.ytb.gov.tr/guncel/aile-ve-sosyal-hizmetler-uzmanlari-egitim-programi. Accessed 20 February 2018.

${ }^{28} \mathrm{https}$ ://www.ytb.gov.tr/guncel/aile-ve-sosyal-hizmetler-alanlarinda-uzmanlik-bursu. Accessed 20 February 2018.
} 


\subsection{Conclusions}

Turkey's diaspora engagement policies have taken different forms since the 1960s. Until acknowledging emigrants' permanent settlement in the host countries, the Turkish state mainly aimed at benefitting from emigration in order to boost economic growth and cut down the unemployment rates. During the 1980s, the Government started to take measures to control and improve the circumstances of the Turkish population in Europe. In the 1990s, further institutional mechanisms were developed to encourage social and political engagement of the Turkish diaspora with the homeland. However, due to domestic security and economic concerns in this period, the Turkish state did not have the adequate resources to fully address the problems of the emigrants (Mencutek and Baser 2018).

Following the transition to a more active foreign policy in the 2000s, Turkey has strived to boost its soft power and to display its increasing competence as a global actor. The shifts in foreign policy mark the start of a new era of Turkish diaspora politics with significant institutional changes. In this new era, one tier of the overall approach of the Turkish state to nationals abroad has been to defend and protect their rights before the host country authorities. The other tier has been to consider them as political and economic contributors, courting both their political influence as 'public diplomats,' and their entrepreneurial activities (Aydin 2014; Mencutek and Baser 2018).

In this context, Turkey's social protection policies mainly focus on helping the emigrants navigate the host country social protection procedures and strengthening their economic, cultural and political ties with the homeland. Many consular social protection services such as in-kind, in-cash and repatriation aids are not present in the framework of social protection policies. Attachés of the Ministry of Family and Social Policies and the Ministry of Labour and Social Security, who work in consulates, mainly concentrate on assistance with host country procedures. In other words, Turkish authorities consider themselves as the facilitator of migrants' access to the welfare entitlements of the destination countries. In this context, the new legal expertise and family and social services programs of the YTB starting in 2018 signal a step forward in the Turkish diaspora engagement policies of social protection.

Among the five core policy areas discussed above, family-related benefits, access to home country pensions, and healthcare stand out as the most significant ones. Family-related benefits have the largest scope with elements such as child benefits, expansion of the related attaché offices, the YTB programs and educational services for children. In line with the Government's emphasis on family values as an intrinsic part of conservative policies, family benefits constitute the broadest social policy area. Protecting the Turkish family values in the host country constitutes an important core for the overall diaspora policy of defending the rights of emigrants, especially regarding discrimination, racism and Islamophobia. In this respect, training social service workers and lawyers employed by host country institutions can also be considered as an example of how Turkey shows its increasing capabilities to the other actors in the global arena. 
The 2018 presidential and legislative elections consolidated the power of the ruling party AKP and its leader Erdogan. Since then, the President and Government have been challenged by the electoral success of the opposition in key Turkish cities in the 2019 local elections and the economic downturn. Despite such challenges, Turkey has continued with an active foreign policy approach in 2019, bringing forward the issues of national security and strategic autonomy. While it has gradually moved away from its traditional Western allies, it has entered in new deals with Russia and continued to build important ties in Africa and Eurasia. Based on the current situation, it is likely that Turkey's active foreign policy approach will continue in the future. In this respect, rather than any major changes or new directions in the diaspora engagement policies, one can expect a strengthening of the already existing approaches. The latest programs added to the agenda of the YTB can be regarded as a proof of this continuing trend.

Acknowledgements This chapter is part of the project "Migration and Transnational Social Protection in (Post)Crisis Europe (MiTSoPro)" that has received funding from the European Research Council (ERC) under the European Union's Horizon 2020 research and innovation programme (Grant agreement No. 680014). In addition to this chapter, readers can find a series of indicators comparing national social protection and diaspora policies across 40 countries on the following website: http://labos.ulg.ac.be/socialprotection/.

\section{References}

Akcapar, S. K. (2009). Turkish Associations in the United States: Towards building a transnational identity. Turkish Studies, 10(2), 165-193.

Aksel, D. B. (2014). Kins, distant workers, diasporas: Constructing Turkey's transnational members abroad. Turkish Studies, 15(2), 195-219.

Al-Shahi, A., \& Lawless, R. I. (2005). Middle East and North African immigrants in Europe. London: Routledge.

Aydin, Y. (2014). The new Turkish diaspora policy: its aims, their limits and the challenges for associations of people of Turkish origin and decision-makers in Germany (working paper). Berlin: Stiftung Wissenschaft und Politik-SWP-Deutsches Institut für Internationale Politik und Sicherheit. https://www.ssoar.info/ssoar/handle/document/41070. Accessed 8 Mar 2019.

Doomernik, J. (1995). The institutionalization of Turkish Islam in Germany and the Netherlands: A comparison. Ethnic and Racial Studies, 18(1), 46-63.

Erdogan, M. M., Karapinar, Y. D., \& Aydinli, D. (2013). Türkiye'nin göç politikası. In M. Yıldız \& M. Z. Sobacı (Eds.), Kати politikası kuram ve uygulama (pp. 422-464). Ankara: Adres Yayınları.

Holzmann, R. (2016). Do bilateral social security agreements deliver on the portability of pensions and health care benefits? A summary policy paper on four migration corridors between $E U$ and non-EU member states. Washington, DC: World Bank.

Kadirbeyoglu, Z. (2007). Changing conceptions of citizenship in Turkey. In B. Perchinig, R. Baubock, \& W. Sievers (Eds.), Citizenship policies in the New Europe (pp. 293-311). Amsterdam: Amsterdam University Press.

Kadirbeyoglu, Z. (2010). Country report: Turkey. Florence: EUDO Citizenship ObservatoryEuropean University Institute.

Mencutek, Z. S., \& Baser, B. (2018). Mobilizing diasporas: Insights from Turkey's attempts to reach Turkish citizens abroad. Journal of Balkan and Near Eastern Studies, 20(1), 86-105. 
Mügge, L. (2012). Managing transnationalism: Continuity and change in Turkish state policy. International Migration, 50(1), 20-38.

Østergaard-Nielsen, E. (2003). Transnational politics: The case of Turks and Kurds in Germany. London: Routledge.

Sirkeci, I., Cohen, J. H., \& Yazgan, P. (2012). Turkish culture of migration: Flows between Turkey and Germany, socio-economic development and conflict. Migration Letters, 9(1), 33.

Unver, C. (2013). Changing diaspora politics of Turkey and public diplomacy. Turkish Policy Quarterly, 12(1), 181-189.

Yanasmayan, Z. (2010). Role of Turkish Islamic organizations in Belgium: The strategies of "Diyanet" and "Milli Görüş". Insight Turkey, 12, 139-161.

Open Access This chapter is licensed under the terms of the Creative Commons Attribution 4.0 International License (http://creativecommons.org/licenses/by/4.0/), which permits use, sharing, adaptation, distribution and reproduction in any medium or format, as long as you give appropriate credit to the original author(s) and the source, provide a link to the Creative Commons license and indicate if changes were made.

The images or other third party material in this chapter are included in the chapter's Creative Commons license, unless indicated otherwise in a credit line to the material. If material is not included in the chapter's Creative Commons license and your intended use is not permitted by statutory regulation or exceeds the permitted use, you will need to obtain permission directly from the copyright holder. 